\title{
Social Assistance for Poverty Reduction in the EU Countries: An Aspect of Socio-Economic Sustainability
}

\author{
Rasa Balvociute ${ }^{1}$
}

\begin{abstract}
Research on the impact of social assistance benefits and other socio-economic indicators on poverty reduction during $2000-2017$ in 24 EU countries is presented in the paper. In order to assess the impact a regression analysis model of the panel data was composed by including such indicators as changes in gross total expenditure per capita, the GDP growth rate, the share of the retirement-age population, the unemployment rate of the working-age population, the long-term unemployment rate. Research findings revealed the main socio-economic indicators that have the greatest impact on changes in poverty. The economic slowdown reduced the at-risk-of poverty gap of people with the lowest income and the economic growth reduced the poverty gap with a lag of two periods (years). The overall impact of all social transfers under analysis on the at-risk-of poverty gap was insignificant. The at-risk-of poverty rate, which shows changes in the share of the most deprived population under analysis, increased when non-targeted and means-tested benefits gal geriau social transfers increased. On the basis of these findings it can be stated that, during the period under analysis, social assistance was not well-directed, i.e. did not focus on the most deprived part of the population.
\end{abstract}

Keywords: sustainable development, social assistance benefits, means-tested benefits, the at-risk-of-poverty rate, the relative poverty gap, panel data.

\section{Introduction}

Sustainable society development covers the implementation of social, ecological and economic objectives and compromises since that helps to maintain the integrity of the whole system. Any imbalance in one factor has an impact on another and infringes sustainable development. In order to establish the causes and potential consequences of imbalances and to choose corrective measures interdisciplinary scientific research built on modern approaches and the assessment of the interaction between factors of different nature are necessary. Policy-makers, concerned with sustainable development, frequently reveal the consequences of imbalances or the results of unsustainable development and identify them as problems requiring solutions building on evidencebased guidelines. Interaction among social and economic factors behind sustainable development of the EU States have been analysed in this paper.

Full eradication of poverty has been the main goal for decades in many countries since that has been identified as the most adverse factors jeopardising balanced society socioeconomic development. As it was laid down in the agenda of the UN General Assembly in 2017 (Transforming Our World: the 2030 Agenda for Sustainable Development, A/RES/, 70/1), primary objectives are poverty reduction and sustainable socio-economic development. Practitioners, while solving these issues, draw on the historically developed approach to poverty reduction - to raise income by developing industry, agriculture and 
services. However, historical data and research analysis show that this process is not sustainable. Economic growth is frequently interrupted by shocks and development imbalances, rapid automation and robotisation of production processes reduce the number of job places. Rapid economic growth boosted by competitiveness can generate higher income but also cause serious environmental and social problems. A growing degree of income redistribution in favour of capital in many countries (Hein, 2016; Tamasauskiene, Seputiene, Balvociute, Berzinskiene-Juozaitiene, 2017; Stockhammer, Rabinovich, Reddy, 2018) increases functional as well as personal income inequality. Social assistance systems, elaborated income distribution schemes and rising social benefits over the last decades in the EU countries (Eurostat, 2018) should ensure sustainable socio-economic development; however, an increase in relative poverty in such commonly recognised welfare states as Denmark and Sweden (Balvociute, 2019) is the consequence of income inequality in these countries and distances them from welfare states. Similar trends have been observed in Germany, Austria, Belgium, Luxemburg, the Netherlands and the Central and the Eastern European countries (except for Poland and Slovakia). Hence, minimum subsistence needs are not ensured for a growing number of citizens in the developed and developing EU countries. In order to ensure sustainable society development, the effectiveness of measures aiming at balanced socio-economic development must be identified and assessed. Research into this issue at macro level is limited by the differences across these countries and a relatively short period of the assessed processes but econometric analysis of panel data expands research opportunities.

The aim of this research is to identify and assess the impact of social assistance benefits and other socio-economic factors on changes in poverty in the EU States.

Research into the impact of social assistance benefits on poverty reduction have been discussed, changes in monetary poverty and social assistance benefits in the EU States have been analysed in the paper. The assessment model of the impact of social assistance benefits on poverty reduction has been constructed and their impact has been assessed across 24 EU States using a regression analysis of the panel data.

\section{Key concepts, descriptive statistics and previous relevant studies}

In $2017,112.8$ million people (22.4\% of the EU population) lived in households at risk of poverty or social exclusion (EUROSTAT Statistics explained, 2019). Although over the last decade the European Commission has been attaching great importance to income inequality and poverty reduction in the Community Member States, but, as statistical data show, the situation has not been improving fast enough, and poverty growth trends remain in some countries (Martin and Swank, 2012; Van Vliet, Wang, 2016). This might have been due to the difference between the effectiveness of the taxation and the social assistance schemes, the aim of which is poverty reduction (Cantillon, 2011), insufficient public financing and income redistribution, market pressures contributing to a rise in prices and related expenses. In order to handle poverty growth in the Member States it is necessary to have a balanced social policy which will ensure a minimum subsistence income for the poorest population and an effective use of social assistance funds. 
A common approach to the assessment of the directedness and effectiveness of social assistance instruments - social insurance, non-targeted and means-tested benefits, social services, etc. and their various combinations - has been lacking in scientific literature. The notion of poverty, its assessment criteria and methods also may be different and make the research object a more complicated issue. For a simpler calculation and assessment and statistical data availability the following indicators are mainly used to define poverty in research papers: income inequality, the scope of poverty (population living in poverty), the relative poverty rate, the poverty gap. The at-risk-of-poverty rate shows the share of the population with disposable income below the at-risk-of-poverty threshold, the at-risk-of-poverty gap is a percentage of the median income of persons below the at-risk-of poverty threshold itself (Eurostat Statistics Explained, Glossary). The values of this threshold vary from 40 to 70 percent of the median disposable income, the at-risk-of-poverty rate and the gap may be different. For example, in EU-27, in 2017, the highest gap between income and the at-risk-of-poverty threshold (31.6\%) was when this threshold was $40 \%$ of the median disposable income. The European Commission (2010) set the at-risk-of-poverty threshold as priority - net income not less than $60 \%$ of the national median income, at the at-risk-of-poverty gap was lower $24.1 \%$. In the same year the at-risk-of-poverty rate $(6.1 \%)$ was of the smallest number of people with the lowest income (40\% of the median disposable income). To sum up, it can be stated that a small part of people lives in extreme poverty but this part has been growing, and poverty deepening. Meanwhile, the number of people with higher income (but not above the $60 \%$ poverty threshold) has been growing.

In scientific literature on poverty, the marginal method is the most frequently used method for estimating the impact of separate social transfers on poverty (Nelson, 2004); it helps us assess the impact of different social transfers (social assurance benefits, nonmeans tested, means-tested benefits, etc.) on poverty reduction in one country. Taking into account the purpose of social assistance benefits, means-tested (or income-tested) benefits should be most effective and ensure a minimum amount of economic resources precisely when other sources of income are insufficient to provide protection against economic hardships and thus prevent people from poverty. These benefits are based on the notion that a certain standard of adequacy in society exists, below which nobody should be allowed to fall (Veit-Wilson 1998). Referring to Beckerman's (1979) model described in scientific literature, the impact of the social transfers under analysis shall be defined on the basis of amounts transferred and induced changes in poverty - by comparing the impact of post-transfer poverty and pre-transfer poverty (Kuivalainen, 2004; Nelson, 2004, 2013). On the basis of this impact assessment model of social transfers, it has been accepted that their impact depends on what group of poor people social transfers are targeted at. If the goal is to reduce extreme poverty, social transfers should be allocated to the most deprived people. If the goal is to move as many people as possible above the at-risk-of-poverty threshold, social transfers should be allocated to the least deprived people. If the goal is to maximise target groups of beneficiaries, social transfers should be allocated to as many deprived people as possible.

Long-term changes in the impact of social transfers on poverty show that during 20052018 their impact decreased in many EU States. This decrease, showed in Fig.1, is expressed as a negative reduction (in percentage) in the at-risk-of-poverty rate due to 
social transfers (calculated by comparing the at-risk-of-poverty rates before social transfers with those after transfers (pensions are not considered as social transfers in these calculations). The impact of social transfers significantly increased only in Ireland, Spain, Poland and the United Kingdom, meanwhile it decreased even in 12 Member States.

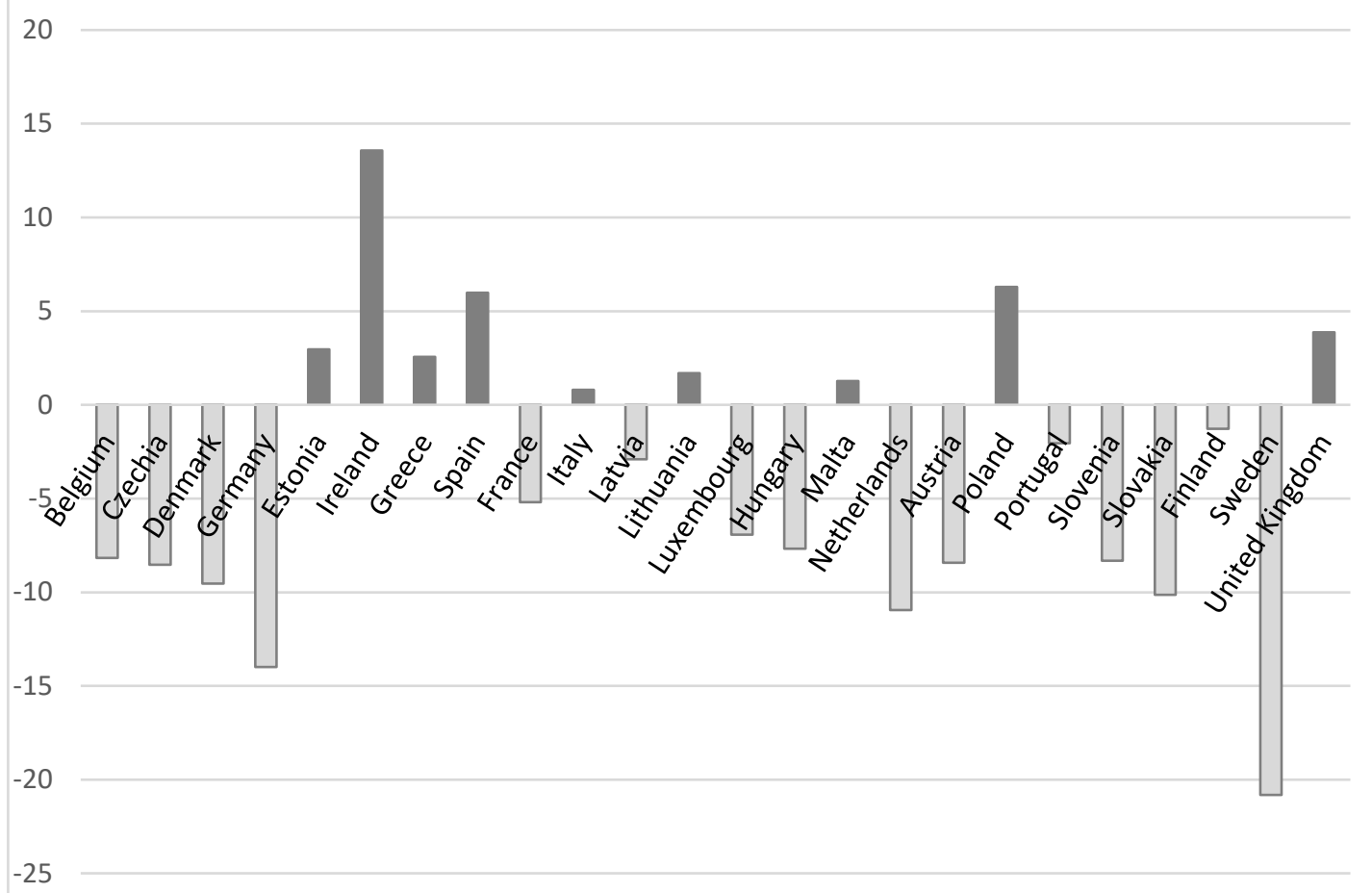

Figure 1. The impact of social transfers (excluding pensions) on poverty reduction in 24 EU States during 2005 2017 in percentage points.

Scientific discussions focus on looking for the best and the most effective poverty reduction instruments. Scientists working on this issue (Esping-Andersen, 2002; Kuivalainen, 2004; Nelson, 2004; Van Vliet, Wang, 2015) say that social security benefits or other social protection benefits are almost ineffective instruments for poverty reduction. Over the last decade, the total amount of social expenditure (on non-targeted and means-tested benefits) has increased in many EU countries although the amounts of separate social benefits have decreased but the number of beneficiaries has increased. This implies the assumption that social assistance systems do not operate effectively, and social assistance rarely helps beneficiaries rise above the at-the-poverty threshold (Nelson, 2013). Policy-makers in the EU States, where expenditure on the implementation of social policy measures is generous (mainly in the old Member States), aim to reform their social assistance systems by drawing on scientific research but often do not go beyond the reduction of targeted benefits or their redistribution (Van Vliet, Wang, 2016). Social assistance expenditure on low-income people is several times smaller in the Central and Eastern European countries, thus, following their accession to the 
EU, they have been aligning their social assistance systems with the ones in the old Member States and increasing their spending on social assistance (Eurostat data [spr_exp_sum]). As statistical data show, during 2005 - 2017, social assistance expenditure in 27 Member States reached 1 billion EUR, but the impact of this instrument is doubtful because the at-risk-of poverty gap was increasing with each year (see Fig. 2).

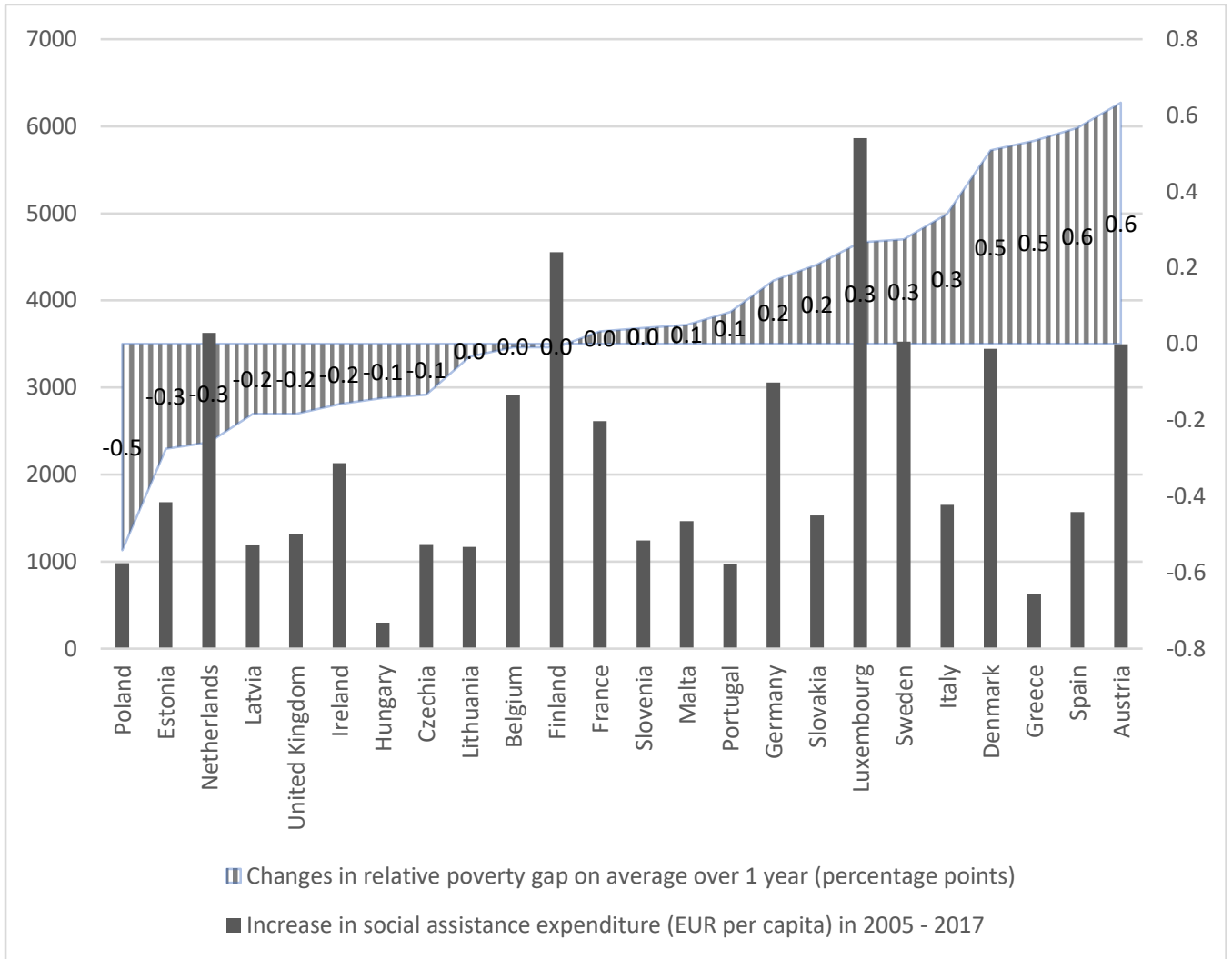

Figure 2. Changes in the relative poverty gap (values on the right axis) in percentage points and an increase in social assistance expenditure in 24 EU States in 2015 - 2017 (values on the left axis) in Euro

The most significant scientific researches on this issue were carried out in several states. Behrendt (2000) analysed the impact of means-tested transfers in the Western Europe and found that the benefits under analysis seldom reduced poverty in Germany, Sweden and the UK. Kuivalainen (2004) investigated anti-poverty measures in 6 countries and carried out a comparative analysis of their impact in 2000. Nelson (2004) assesed the impact of social assistance benefits in 1990 in 5 countries with different types of welfare state models. He analysed the impact of social benefits on poverty by including microeconomic variables that had not been analysed in terms of dynamic changes. Noland and Marx (2009) analysed the situation in 24 OECD countries and said that social assistance benefits had a significant impact on poverty but this study did not cover the whole panel. Caminada, Goudswaard, Koster (2012) carried out a regression analysis that covered 1985 - 2005 and, using the OLS model across 15 Member States, found a positive 
impact only of private social assistance transfers on poverty alleviation. The authors also pointed out that unemployment and an ageing population had a rather significant impact on poverty. In one of their most recent studies, Van Vliet, Wang (2016) assessed the impact of social transfers during 1997 - 2007 across 15 Member States, carried out panel data regression analysis but found no significant impact of government expenditure on changes in poverty. Employment and trade (\% of GDP) had the most significant impact on the at-risk-of-poverty employed people but it was negative: higher employment and larger trade volumes tended to increase poverty.

The impact of social assistance benefits on the poverty level or income inequality was analysed in the mentioned studies, but the impact of separate social assistance forms on the relative poverty gap was insufficiently addressed, particularly with a long-term view. There is also a lack of research into the assessment of the impact on changes in poverty of not only social assistance benefits but also of other socio-economic factors.

\section{The econometric approach and the hypotheses}

The impact of social assistance benefits was assessed in 24 Member States and a regression analysis of panel data was carried out. Panel data consist of repeated observations over time on the same set of cross-sectional units. The advantages of the analysis of panel data over the analysis of pure time series and pure cross-sectional data is that panel data allow us to keep individual heterogeneity under control and give less colinearity among the variables (Baltagi, 2005). Panel data provide more informative data, more variability, more degrees of freedom and more efficiency thus the estimates are more reliable since all that opens up the possibility to study variations over time and across sections.

The aim of this research was to identify how poverty indicators change when the variables that define socio-economic factors change during the analysed period. Having constructed and tested the initial impact assessment model it was found that the dependent variables (the relative poverty gap and the at-risk-of-poverty rate) are under the impact of their own lagging behind variables therefore a regression model for dynamic panel data analysis was chosen. Changes in the impact of social assistance benefits (non-targeted and means-tested) on the at-risk-of poverty threshold were analysed and the elasticity coefficients of these changes were calculated.

Building on previous research and descriptive statistics the following hypotheses were formulated:

H1: Rises in social assistance benefits (non-targeted and means-tested) and economic growth reduce the at-risk-of poverty gap;

H2: Population ageing, unemployment of the working-age population and a long-term unemployment increase the at-risk-of-poverty gap.

\subsection{The data set and variables}

The following Eurostat data were used: GDP per capita in 2010 (EU-SILC [nama_10_pc]), the relative poverty gap 40\% of the median equivalised income by the poverty threshold (EU-SILC [ilc_li11]), social protection expenditure per inhabitant (EU-SILC [spr_exp_fto]), social protection benefits and means-tested benefits, 
population over the age of 60 (EU-SILC [pc_y60_max]), unemployment of active population (EU-SILC [une_rt_a]), long-term unemployment (EU-SILC [pc_y60_max]). Cross-sectional data covered 24 EU countries, time series data - $2000-2017$ period. Due to the lack of the data on the relative poverty gap and the at-risk-of-poverty rate during 2002 - 2004 in the countries under analysis, the data for 2005 were included assuming that there were no essential changes in poverty indicators during a three-year period. Thus, it can be said that although the panel data were not balanced but were calculated following the same calculation and classification methods therefore can be considered to be homogeneous. The values of the variables were differentiated and logarithmized.

\subsection{The model specification}

On the basis of relevant scientific literature (Caminada, Goudswaard, Koster, 2012; Van Vliet, Wang, 2016), an econometric model with panel data was composed, the share of the population over the age of 60 , changes in the share of the working age unemployed population and the level of long-term unemployment were included into it as independent variables. A change in an exogenous economic growth (GDP per capita) factor, the impact of which can be lagging behind, was also included. Since a strong correlation between economic growth and changes in all social benefits and means-tested benefits was found, three models consisting of each of these variables were composed. Due to autocorrelation there was no likelihood to include changes in unemployment among working age people and long-term unemployment at the same time. In order to assess the impact of social transfers on the poverty scope and depth, the at-risk-of-poverty rate and the relative poverty gap were included as dependent variables.

$$
\begin{aligned}
& \Delta \ln \left(R_{-} P_{0} v_{-} \text {Rate }_{i, t}\right)=\alpha+\Delta_{4} t d 2003+\ldots+\Delta_{19} t d 2017+\beta_{1} \Delta \ln \left(G D P_{i, t-2}\right)+
\end{aligned}
$$

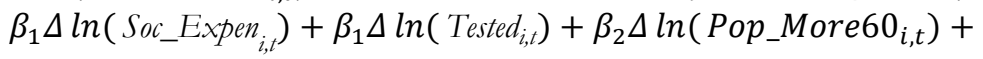

$$
\begin{aligned}
& \beta_{3} \Delta \ln \left(\text { Unempl_Activ }_{i, t}\right)+\beta_{3} \Delta \ln \left(\text { Pers_Unempl }_{i, t}\right)+\gamma \Delta \ln \left(R_{-} \text {Pov_Gap }_{i, t-1}\right)+\Delta u_{i, t} \\
& \Delta \ln \left(R_{-} P o v_{-} G_{a p}, t\right)=\alpha+\Delta_{4} t d 2003+\ldots+\Delta_{19} t d 2017+\beta_{1} \Delta \ln \left(G D P_{i, t-2}\right)+ \\
& \beta_{1} \Delta \ln \left(\text { Soc_Expen }_{i, t}\right)+\beta_{1} \Delta \ln \left(\text { Tested }_{i, t}\right)+\beta_{2} \Delta \ln \left(\text { Pop_More60 }_{i, t}\right)+ \\
& \beta_{3} \Delta \ln \left(\text { Unempl_Activ }_{i, t}\right)+\beta_{3} \Delta \ln \left(\text { Pers_Unempl }_{i, t}\right)+\gamma \Delta \ln \left(R_{-} \text {Pov_Gap }_{i, t-1}\right)+\Delta u_{i, t}
\end{aligned}
$$

Choosing the most appropriate assessment method it was taken into account that asymmetrical data distribution is the most often observed type of distribution, moreover, due to gaps in the data and artificial but required variables, exemptions are possible but that contradicts the OLS assumptions. Scientific research shows that endogeneity is a characteristic property of some independent variables, i.e. these variables correlate with errors. Autocorrelation and endogeneity condition that the coefficients calculated using the generalised OSL are displaced and uncoordinated. Therefore, this method was rejected as irrelevant for this research although it is most popular among researchers. The generalised method of moments (GMM), which allows the OLS method problems, mentioned above, to be solved, has been used in the most recent research on the impact of socio-economic variables on poverty. In the GMM, in contrast to the OLS, there is no 
assumption about data distribution (i.e. normal and asymmetric) therefore potentially not normally distributed variables shall not affect results. Moreover, using the GMM, the problems of endogeneity and error autocorrelation can be solved.

Having taken into account data availability the period from 2000 to 2017 was chosen for analysis. Since the values of several independent variables (expenditure for social benefits and means-tested benefits) were missing for a certain period, using the GMM systematically an unbalanced panel data set was assessed. An unbalanced panel data set allows a longer period to be chosen for analysis, what means a bigger number of observations and potentially more accurate research results. All estimates were calculated using a dynamic panel data model and a one-step GMM estimator. Time dummies were included into all models.

Although the GMM model excludes assumptions about data distribution, however, the GMM follows two assumptions. Firstly, the GMM estimates are relevant when the model is not characterised by second-order autocorrelation. Secondly, the model should not be overvalued, i.e. instruments should be appropriate. Error autocorrelation (firstorder and second-order autocorrelation) was performed using the Arrelano-Bond test. Test results: a null hypothesis that first-order autocorrelation is uncharacteristic of the model was rejected. But the hypothesis that second-order autocorrelation does not exist cannot be rejected at a significance level of 5\%. First-order autocorrelation has no impact on the reliability of the GMM estimates, they are distorted only by second-order autocorrelation. Consequently, the use of a dynamic panel model with several instrumental variables is valid because it allows second-order autocorrelation to be removed. Finally, one more test was run for the purpose of checking parameter reliability limitations of a statistical model. A null hypothesis in the Wald test says that all coefficients statistically do not differ from zero. In the Wald test, when p-value is less than a significance level of $5 \%$, a hypothesis is rejected and statistically coefficients insignificantly differ from zero. To sum up, it can be concluded that the tests imply that the model, in general, is a good fit for purpose.

\subsection{Research results}

Assessing the impact of social assistance benefits and of other socio-economic variables on changes in the scope of poverty it was found that only one model is statistically significant. It was found that a rise in the share of the population aged over 60 by 1 percentage point results in a rise in the at-risk-of-poverty rate by 0.01 percentage point, a similar rise in long-term unemployment - in a rise in the at-risk-of-poverty rate by 0.035 percentage points. If social assistance benefits of all types increase by 1 percentage point, the at-risk-of-poverty rate drops by 0.5 percentage points. The other two models failed to address the autocorrelation problem thus their results are not reliable.

The impact of social assistance benefits (non-targeted and means-tested) on changes in the poverty gap were not statistically significant (see Table 1). A positive impact of economic growth lagging behind for 2 periods on the poverty gap was found. If economy grows by 1 percentage point, the poverty gap decreases by over 1 percentage point. But, interpreting these results, the impact of changes over the economic cycles must be taken into account. For example, during 2008 - 2009, when economies shrank 
as a consequence of the financial crisis followed by economic recession, the scope and depth of poverty decreased in all countries under analysis. That was due to endogenous growth and relative poverty, when declining income of the population reduces the national median income, and then people on low but stable income can rise above the poverty threshold. Thus, hypothesis 1 was validated only in part but a lagging behind impact of economic growth on poverty occurred only in the long run.

Table 1. The impact of economic growth (changes in GDP) and social transfers on the at-risk-ofpoverty gap when the relative poverty gap is $40 \%$ of the median equivalised income

\begin{tabular}{|c|c|c|c|c|c|c|}
\hline & (1) & (2) & (3) & (4) & (5) & (6) \\
\hline Ld R_Pov_Gap(-1) & $\begin{array}{l}-0.31 * * * \\
(1.32 \mathrm{e}-011)\end{array}$ & $\begin{array}{l}-0.32^{* * *} \\
(1.47 \mathrm{e}-011)\end{array}$ & $\begin{array}{l}-0.29 * * * \\
(4.74 \mathrm{e}- \\
09)\end{array}$ & $\begin{array}{l}-0.3^{* * *} \\
(2.28 \mathrm{e}- \\
08)\end{array}$ & $\begin{array}{l}- \\
0.313 * * * \\
(6.60 \mathrm{e}- \\
010)\end{array}$ & $\begin{array}{l}- \\
0.324 * * * \\
(1.04 \mathrm{e}- \\
09)\end{array}$ \\
\hline$\alpha$ & $\begin{array}{l}-1.38 \\
(0.22)\end{array}$ & $\begin{array}{l}-1.28 \\
(0.3)\end{array}$ & $\begin{array}{l}0.11 \\
(0.9)\end{array}$ & $\begin{array}{l}0.35 \\
(0.9)\end{array}$ & $\begin{array}{l}0.9 \\
(0.77)\end{array}$ & $\begin{array}{l}1.5 \\
(0.7)\end{array}$ \\
\hline $\operatorname{td} 2003$ & $\begin{array}{l}1.77 \\
(0.38)\end{array}$ & $\begin{array}{l}1.84 \\
(0.39)\end{array}$ & $\begin{array}{l}0.32 \\
(0.9)\end{array}$ & $\begin{array}{l}-0.015 \\
(0.99)\end{array}$ & $\begin{array}{l}-1.64 \\
(0.63)\end{array}$ & $\begin{array}{l}-2.59 \\
(0.49)\end{array}$ \\
\hline$\ldots$ & $\ldots$ & $\ldots$ & $\ldots$ & $\ldots$ & $\ldots$ & $\ldots$ \\
\hline $\operatorname{td} 2017$ & $\begin{array}{l}1.4 \\
(0.5)\end{array}$ & $\begin{array}{l}0.8 \\
(0.7)\end{array}$ & $\begin{array}{l}0.11 \\
(0.96)\end{array}$ & $\begin{array}{l}-0.56 \\
(0.79)\end{array}$ & $\begin{array}{l}0.56 \\
(0.8)\end{array}$ & $\begin{array}{l}-1.33 \\
(0.55)\end{array}$ \\
\hline$\Delta \ln \left(\mathrm{GDP}_{\mathrm{i}, \mathrm{t}-2}\right)$ & $\begin{array}{l}-1.35^{* * *} \\
(0.002)\end{array}$ & $\begin{array}{l}-1.29 * * * \\
(0.004)\end{array}$ & & & & \\
\hline$\Delta \ln \left(\right.$ Soc_Expen $\left._{i, t}\right)$ & & & $\begin{array}{l}0.92 * * \\
(0.04)\end{array}$ & $\begin{array}{l}0.72 \\
(0.13)\end{array}$ & & \\
\hline$\Delta \ln \left(\right.$ Tested $\left._{\mathrm{i}, \mathrm{t}}\right)$ & & & & & $\begin{array}{l}0.03 \\
(0.88)\end{array}$ & $\begin{array}{l}-0.12 \\
(0.6)\end{array}$ \\
\hline$\Delta \ln \left(\right.$ Pop_More60 $\left._{\mathrm{i}, \mathrm{t}}\right)$ & $\begin{array}{l}0.111 \\
(0.277)\end{array}$ & $\begin{array}{l}0.09 \\
(0.39)\end{array}$ & $\begin{array}{l}0.17 \\
(0.16)\end{array}$ & $\begin{array}{l}0.17 \\
(0.24)\end{array}$ & $\begin{array}{l}0.234^{* *} \\
(0.03)\end{array}$ & $\begin{array}{l}0.22^{*} \\
(0.07)\end{array}$ \\
\hline$\Delta \ln \left(\right.$ Unempl_Act $\left.{ }_{i, t}\right)$ & $\begin{array}{l}0.5^{* * *} \\
(2,11 \mathrm{e}-014)\end{array}$ & & $\begin{array}{l}0.63^{* * *} \\
(8.17 \mathrm{e}- \\
017)\end{array}$ & & $\begin{array}{l}0.54 * * * \\
(2.54 \mathrm{e}- \\
013)\end{array}$ & \\
\hline$\Delta \ln \left(\right.$ Pers_Unempl $\left.{ }_{i, t}\right)$ & & $\begin{array}{l}0.11 * * * \\
(4,64 \mathrm{e}-06)\end{array}$ & & $\begin{array}{l}0.1^{* * *} \\
(0.0006)\end{array}$ & & $\begin{array}{l}0.07 * * \\
(0.02)\end{array}$ \\
\hline $\operatorname{AR}(1)$ & $\begin{array}{l}-4.53 \\
{[0.0000]}\end{array}$ & $\begin{array}{l}-4.4 \\
{[0.0000]}\end{array}$ & $\begin{array}{l}-4.41 \\
{[0.0000]}\end{array}$ & $\begin{array}{l}-4.32 \\
{[0.0000]}\end{array}$ & $\begin{array}{l}-4.48 \\
{[0.0000]}\end{array}$ & $\begin{array}{l}-4.39 \\
{[0.0000]}\end{array}$ \\
\hline $\operatorname{AR}(2)$ & $\begin{array}{l}-2.8 \\
{[0.0049]}\end{array}$ & $\begin{array}{l}-2.77 \\
{[0.0055]}\end{array}$ & $\begin{array}{l}-1.98 \\
{[0.0472]}\end{array}$ & $\begin{array}{l}-2.15 \\
{[0.032]}\end{array}$ & $\begin{array}{l}-2.22 \\
{[0.027]}\end{array}$ & $\begin{array}{c}-2.47 \\
{[0.01]}\end{array}$ \\
\hline $\mathrm{n}$ & 360 & 360 & 350 & 350 & 352 & 352 \\
\hline $\begin{array}{lr}\text { Sargan } & \text { over- } \\
\text { identification } & \text { test } \\
\text { Chi-square133 } & \text { for } \\
\text { 1,2 models;134 } & \text { for } \\
3-6 \text { models } & \\
\end{array}$ & $\begin{array}{l}516.5 \\
{[0.0000]}\end{array}$ & $\begin{array}{l}521.2 \\
{[0.0000]}\end{array}$ & $\begin{array}{l}517.3 \\
{[0.0000]}\end{array}$ & $\begin{array}{l}526.7 \\
{[0.0000]}\end{array}$ & $\begin{array}{l}505.9 \\
{[0.0000]}\end{array}$ & $\begin{array}{l}511.7 \\
{[0.0000]}\end{array}$ \\
\hline Wald (joint) test & $\begin{array}{l}137.5 \\
{[0.0000]}\end{array}$ & $\begin{array}{l}107.9 \\
{[0.0000]}\end{array}$ & $\begin{array}{l}131.5 \\
{[0.0000]}\end{array}$ & $\begin{array}{l}158.4 \\
{[0.0000]}\end{array}$ & $\begin{array}{l}153.2 \\
{[0.0000]}\end{array}$ & $\begin{array}{l}103.7 \\
{[0,0000]}\end{array}$ \\
\hline
\end{tabular}


Changes in unemployment of the working age population and long-term unemployment had the biggest negative impact on poverty. When the unemployment level rose by 1 percentage point, the poverty gap increased by $0,5-0,63$ percentage points. The impact of long-term unemployment was smaller. Changes in unemployment (of the working age population and long-term unemployment) are pro-cyclical and spontaneous in terms of changes in poverty: a rise in unemployment in that year always results in greater poverty. The impact of an increase in the share of persons over the age of 60 was not statistically significant. It shows that hypothesis 2 was validated but also only in part.

Attempts to compose models for the assessment of the impact of the share of the population with higher income $(50 \%, 60 \%, 70 \%$ of the median disposable income) but still at the risk of poverty on the poverty gap were not successful due to high levels of endogeneity in independent variables. But, verifying models for fixed and random effects, some indicators, which may suggest that social assistance benefits (particularly non-targeted benefits) may reduce the poverty gap of people with a little higher income but not of the poorest were found. This assumption needs to be validated in further research.

\section{Conclusions and discussion}

Poverty is one of the main characteristics of unsustainable socio-economic development. Society polarisation, geopolitical conflicts, economic migration are the most often named consequences of poverty. Traditionally, those countries, that joined the EU before the 21st century, for over the last 50 years have been referred to as affluent. They are welfare states where the issue of poverty is no longer vital. But that refers to absolute poverty whereas relative poverty has been rising despite economic growth. After the EU enlargement of 2004, the economies of the Central and Eastern European countries have been developing exceptionally rapidly, but the poverty level (before accession it was higher than in the old Member States) is still on the rise in some of them (in Estonia, Latvia, Hungary and Slovenia). Key factors underlying the risk of poverty - economic growth and changes in unemployment - are working in the opposite directions, but research showed that the impact of economic growth is indirect and lagging behind. Economic growth may not reduce the risk of poverty of people with professions not in demand on the labour market. Changes in unemployment and the risk of poverty occur simultaneously and are directly linked up - higher unemployment always results in a higher risk of poverty. Unemployment benefits are meant to reduce the risk of poverty but they are too small or are granted for a short period (Vanhercke, Natali, Bouget, 2017). As the European Social Policy Network (ESPN) ${ }^{1}$ experts have acknowledged, social benefits, in case of long-term unemployment, have been effective only in 4 States: Cyprus, the Principality of Lichtenstein, Island and the Netherlands. Poverty reduction among the long-term unemployed is still a challenge for other countries.

Over the last 17 years two negative trends have been observed in the EU-28: 1) a rapidly increasing share of the population with income below $60 \%$ of the median disposable

1 http://ec.europa.eu/social/ main.jsp?catId=1135\&langId=en 
income; 2) a widening poverty gap of the population with the lowest income. That means that this share of the population has been becoming more consolidated and impoverished. On the other hand, the share of the population with income higher than the lowest income (but not above the poverty threshold) has been increasing. A wider use of means-tested benefits because they are properly targeted is the most often named instrument to address the first problem (European Commission, 2015). However, research across the EU-24 showed that means-tested benefits, a poverty balancing instrument by reducing the poverty gap, in principle were ineffective. Thus, a new more targeted policy of income redistribution to ensure minimum income for the poorest is needed. A solution to the second problem less depends on the redistribution of social benefits and income. The main cause of this problem is growing income inequality, thus reduced income inequality could result in reduced the risk of poverty.

\section{References}

Baltagi, B.H. (2005). Econometric Analysis of Panel Data. 3rd Edition, John Wiley \& Sons Inc., New York.

Beckerman, W. (1979). The impact of income maintenance payments on poverty in Britain, 1975. The Economic Journal, 89(354), 261-279.

Behrendt, C. (2000). Do means-tested transfers alleviate poverty? Evidence on Germany, Sweden and the United Kingdom from the Luxembourg Income Study. Journal of European Social Policy. 10. $23-41$.

Caminada, K., Goudswaard, K. P., Koster, F. (2012). Social income transfers and poverty: a cross country analysis for OECD countries. International Journal of Social Welfare, 21: 2, 115-26.

Esping-Andersen, G. (1990). The Three Worlds of Welfare Capitalism. Cambridge: Polity Press.

Esping-Andersen, G., Gallie, D., Hemerijck, A., Myles, J. (2002). Why We Need a New Welfare State. Oxford: Oxford University Press.

European Commission (2010). Europe 2020: A Strategy for Smart, Sustainable and Inclusive Growth. Communication COM (2010) 2020. Brussels: European Commission.

EUROSTAT Statistic Explained (2019). People at risk of poverty or social exclusion. Retrieved from https://ec.europa.eu/eurostat/statistics-explained/index.php/ People_at_risk_of_ poverty_or_social exclusion

Hein, E. (2016). Distribution and Growth after Keynes: A Post-Keynesian Guide. Edward Elgar Publishing.

Korpi, T., Nelson, K., Stenberg, S. (2007). The Accumulation of Social Problems: Multiple Deprivation in Sweden 1974-2000. International Journal of Social Welfare, 16: 1, 91-103.

Korpi, W., Palme, J. (1998). The Paradox of Redistribution and Strategies of Equality: Welfare State Institutions, Inequality and Poverty in the Western Countries. American Sociological Review, 63 (5), $661-687$.

Kuivalainen, S. (2004), A Comparative Study on Last Resort Social Assistance Schemes in Six European Countries. Research Report No. 146. Gummerus: Saarijärvi.

Nelson, K. (2004). Mechanisms of Poverty Alleviation in the Welfare State. A Comparative Study of Antipoverty Effects of Non Means-tested and Means-tested Benefits in Five Countries in the 1990. Journal of European Social Policy, 14: 4, 371-390.

Nelson, K. (2013) Social Assistance and EU Poverty Thresholds 1990-2008. Are European Welfare Systems Providing Just and Fair Protection Against Low Income? European Sociological Review, 29(2), 386401.

Nolan, B., and I. Marx (2009). Economic Inequality, Poverty, and Social Exclusion' in: W. Salverda, B. Nolan, T.M. Smeeding (eds.). The Oxford Handbook of Economic Inequality.New York: Oxford University Press, 315-341.

Stockhammer, E., Rabinovich J., Reddy, N. (2018). Distribution, wealth and demand regimes in historical perspective. FMM Working Paper 14-2018, IMK at the Hans Boeckler Foundation, Macroeconomic Policy Institute. 
Tamasauskiene, Z., Seputiene J., Balvociute, R., Berzinskiene-Juozainiene, D. (2017). The impact of wage share on domestic demand in the European Union. Eurasian Economic Review, vol. 7, issue 1, 115132.

Van Vliet, O., Wang C. (2015) Social investment and poverty reduction: A comparative analysis across 15 European countries. Journal of Social Policy, 44(3), 611-638.

Veit-Wilson, J. (1998). Setting adequacy standards: How governments define minimum incomes. Bristol: Policy Press.

Wang, J., and O. van Vliet (2016). Social assistance and minimum income benefits: Benefit levels, replacement rates and policies across 26 OECD countries, 1990-2009. European Journal of Social Security, 18(4), 333-555. 